\title{
Social Intelligence of a Teacher as a Factor of the Stimulation of Cognitive Interests of Students
}

\section{Соціальний інтелект учителя як чинник стимулювання пізнавальних інтересів учнів}

\section{Eduard Ivashkevych}

Dr. in Psychology, Professor, Rivne State University of the Humanities, Rivne (Ukraine)

ORCID ID: https://orcid.org/0000-0003-0376-4615

Researcher ID: http://www.researcherid.com/rid/V-8872-2018

E-mail: ivashkevych.e@gmail.com

\section{Едуард Івашкевич}

Доктор психологічних наук, професор, Рівненський державний гуманітарний університет, м. Рівне (Україна)

\section{Liana Onufriieva}

Dr. in Psychology, Professor, Head of the Department of General and Applied Psychology, Kamianets-Podilskyi National Ivan Ohiienko University, Kamianets-Podilskyi (Ukraine)

ORCID ID: https://orcid.org/0000-0003-2442-4601

Researcher ID: http://www.researcherid.com/rid/R-5598-2018

Scopus Author ID: 57214601047

E-mail: onufriieva@kpnu.edu.ua

\section{Ліана Онуфрієва}

Доктор психологічних наук, професор, завідувач кафедри загальної та практичної психології, Кам'янець-Подільський національний університет імені Івана Огієнка, м. Кам'янець-Подільський (Україна)

Address for correspondence, e-mail: kpnu_lab_ps@ukr.net Copyright: (C) Ivashkevych Eduard, Onufriieva Liana

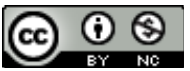
The article is licensed under CC BY-NC 4.0 International (https://creativecommons.org/licenses/by-nc/4.0/)

(C) Ivashkevych Eduard, Onufriieva Liana

DOI (article): https://doi.org/10.32626/2227-6246.2021-54.34-56 http://journals.uran.ua/index.php/2227-6246 
DOI: https://doi.org/10.32626/2227-6246.2021-54

2021. випуск 54

The contribution of the author: Ivashkevych E. - 50\%, Onufriieva L. - 50\%. Авторський внесок: Івашкевич Е. - 50\%, Онуфрієва Л. - 50\%.

\section{ABSTRACT}

The purpose of the article is: to provide the experimental research of social intelligence of a teacher as a factor of the stimulation of cognitive interests of pupils.

Methods of the research. The following theoretical methods of the research were used to solve the tasks formulated in the article: a categorical method, structural and functional methods, the methods of the analysis, systematization, modeling, generalization. Also in our research we used empirical methods, such as statement study and molding experiment. With the aim to diagnose the level of the development of social intelligence of teachers we used the test of J. Gilford and M. O'Sullivan "Research of Social Intelligence», adapted by O.S. Mykhailova.

The results of the research. The data obtained was indicated that women (teachers of the natural sciences) were more sensitive to the nature and various manifestations of human relationships and they were able to show considerable role of flexibility in the situations that were arisen. This may be explained by the fact that education in the paradigm of "love» (passion) for the natural sciences contributes to the development of women's style aimed at emotional sensitivity, communicative compatibility. Men, on the contrary, are encouraged to develop the ability to hide and suppress their feelings, that is, emotional restraint, competition, activity, the ability to control the situation are encouraged.

So, speaking about social intelligence and its role in teaching activities, the latter should be analyzed in terms of the impact on its productivity, efficiency and conditions of optimization. It should be noted that in the pedagogical activity the concept of "productivity» is considered from the point of view of two positions: functional and psychological productivity. The functional productivity of the teacher's activity is as a clearly constructed system of didactic methods and techniques, the basic updating of which are communicative skills. In such a way psychological productivity is the newness of the personality of a student, the level of his/her social adaptation that will contribute to the process of the development of social intelligence.

Conclusions. Taking into account the specifics of each particular object, pedagogical activity is built upon the laws of communication. In any classifications the structure of communication in the foreground appears its cognitive aspect, which largely determines the productivity of teaching activities. Thus,

(C) Ivashkevych Eduard, Onufriieva Liana DOI (article): https://doi.org/10.32626/2227-6246.2021-54.34-56 
we revealed the regularities of the influence of the level of productivity on the understanding of the behavior of the partner in communication, which indicates the actualization of social intelligence. We found that teachers with a low level of pedagogical activity can only perceive external manifestations of the communication of partners, also their behavior without analyzing its goals and motives. However, teachers with a high level of productivity of pedagogical activities can understand the deep essence of the personality-integrational properties of the person, identifying the goals and motives of his/her behavior.

Consequently, the productivity of teaching activity directly depends on the effectiveness of the knowledge of a teacher on the personality of students, that is, it depends on socio-perceptual peculiarities of both - a teacher and pupils.

To our mind, social intelligence of a teacher is updated due to the mechanisms of knowledge of a teacher the pupils' personal qualities and characteristics. One of such mechanisms is pedagogical social-perceptual stereotyping. For the first time this mechanism was investigated in the experiments, in which positive and negative stereotyping of the pupils' personal qualities and characteristics were determined. Also, we identified the influence of evaluative standard stereotypes on social-perceptual stereotyping. It was proved that the negative influence on interpersonal interaction in the pedagogical process had stereotypes that were taking into account an absolute, unchanging character, but for each teacher there were subjective evaluative stereotypes and the teacher focused on their content for the purpose of the actual subjective assessment of the pupil's personality. Then subsequently, this mechanism of pedagogical activity will facilitate the study of personal qualities and characteristics from a professional point of view. In turn, all this indicates a significant level of the development of social intelligence of a teacher.

Key words: social intelligence, stimulation of cognitive interests of students, interpersonal interaction, communication, emotional sensitivity, communicative compatibility.

\section{Introduction}

The problem of the organization of psychological and pedagogical activity and the main conditions of its optimization is one of the most actual in Psychology. The development of the problem of psychological and pedagogical activity is reflected in the articles of scientists (Гончарук \& Онуфрієва, 2018). However, as a rule, the scientific analysis of the components C) Ivashkevych Eduard, Onufriieva Liana

DOI (article): https://doi.org/10.32626/2227-6246.2021-54.34-56 
of psychological and pedagogical activity is limited to the discussion of separate aspects of psychological and pedagogical skills of a teacher. Therefore, in this regard, the most promising area is related to a systematic approach to the analysis of pedagogical activities by the developing of the teachers' and pupils' social intelligence.

Thus, if the cognitive activity in the psychological-pedagogical literature (Onufriieva \& Ivashkevych, 2021) is understood as characteristics of the person or as a character of the pupils' activity, then the stimulation of cognitive activity is shown by us as a deliberate activity of the teacher in the process of learning.

Another point of view is proposed by us by such a suggestion that stimulating the learning process is the way improving the methods and organizational forms of educational activity, which provide active and independent theoretical and practical activities of pupils in all parts of the educational process.

Stimulation of educational and cognitive activity is a process aimed at strengthening the joint educational and cognitive activity of teachers and pupils, on the incentive for its vigorous, purposeful implementation, to overcome inertia, passivity and stereotyped forms of teaching and learning. And also the stimulation of the activities of pupils can not be considered in the current conditions of university development only as a process of leadership activity of students. This is at the same time the process of activating a pupils of his/her own activity.

The stimulation of students' learning should be understood as the mobilization of the teacher (with the help of special means) of the intellectual, moral-volitional and physical forces of the students to achieve the specific goal of education and upbringing. In other words, the activation of pupils we understand as the process and the result of stimulating the activity of students.

Some other scientists (Mykhalchuk \& Kryshevych, 2019) also think that the activation of cognitive activity is a para-

(c) Ivashkevych Eduard, Onufriieva Liana DOI (article): https://doi.org/10.32626/2227-6246.2021-54.34-56 
DOI: https://doi.org/10.32626/2227-6246.2021-54

2021. випуск 54

digm of a system of actions of a teacher, creating incentives which encourage pupils to be actively involved into the process of mastering the educational material, to form their cognitive autonomy.

Of course, cognitive autonomy as personal characteristics manifests itself and it is formed in the process of pupils' activity. In this case, it is characterized by a number of features that in the behavior of pupils find a specific explication of such stimuli:

- the presence in the process of cognitive activity valuable life benchmarks;

- social orientation of the person for the acquisition of knowledge, skills and abilities;

- need for knowledge as the most important motive of providing cognitive activity;

- showing great interest in the process of cognition, autonomy, responsibility and creative attitude to solving cognitive tasks;

- desire of a teacher to find his/her own approach to a new task, to identify the initiative in the process of teaching;

- mastering the means of cognitive activity, the ability to think independently, to highlight the main thing, to analyze, to generalize;

- showing the possession of skills and different ways of learning skills;

- the desire to be deepen and to expand the knowledge and the means of their assimilation to use additional sources of information, for self-education;

- the ability to apply into practice the ways of learning material, to use it for solving the tasks and gaining new knowledge;

- great desire to share the knowledge and the experience with other students, to help them in the organization of their cognitive activity;

- active participation in extra-curricular activities.

C Ivashkevych Eduard, Onufriieva Liana

DOI (article): https://doi.org/10.32626/2227-6246.2021-54.34-56 
These indicators provide a sufficient representation of the close unity of the motivational and operational aspects of cognitive activity of pupils, their successful interaction.

Proceeding from the concept of the child's stage of the personal development (Nunan, 2003) and taking into account the basis for the need for gaining knowledge, the teacher will determine the main stages to pass through them in the development of students' cognitive activity. Each of them is also marked by quantitative and qualitative changes. So, the process of cognitive activity has the following characteristics:

- curiosity, caused by the initial interest in learning and a need for gaining knowledge about the realities;

- responsible attitude towards studying, which is determined by socially significant motives;

- desire for satisfaction of cognitive interest;

- cognitive independence;

- great admiration for the desire for providing scientific research.

We think all these characteristics of cognitive activity lead to a conscious process of learning of students, to some desired effects of the whole process of studying.

Undoubtedly, the consideration of the essence of the stimulation of cognitive activity and the concepts related to it by different authors from different positions, on the one hand, develops the concepts, because, from one hand, its essence is analyzed from different sides, and, on the other hand, such a multiplicity of approaches complicates the formation of a single point of view. Therefore, one can not distinguish some basic and accurate explanation of the concept of activating cognitive activity of pupils.

Summarizing the ideas expressed by the researchers, we can draw the following conclusions:

- the main purpose of stimulation is to improve the quality of the educational process at the university, which is

(C) Ivashkevych Eduard, Onufriieva Liana DOI (article): https://doi.org/10.32626/2227-6246.2021-54.34-56 
DOI: https://doi.org/10.32626/2227-6246.2021-54

2021. випуск 54

achieved by forming the students' activity and their independence;

- the process of formation of the activity and the independence which requires a certain joint activity of students and teachers;

- the stimulation of cognitive activity involves the use of various methods, means, forms of learning that motivate a person to detect the activity. This requires such organization of the process of cognition in which the object of knowledge is included into the field of students' activity and the dialectical interaction between them creates the preconditions for identifying the activity of each person of the dialogical process.

Consequently, the activity in learning is not just an active plan of the lesson, but the quality of this activity, which reveals the personality of the student himself/herself with his/ her attitude to the content, the nature of the activity and the desire to mobilize pupils' moral and volitional efforts to achieve educational and cognitive tasks. At the lesson the teacher specifically creates certain conditions and uses a system of means, the implementation of which provides the activation of learning, that is the concentration of intellectual, moral-volitional and physical forces of students. The choice of means of activation and conditions of learning depends on the level of cognitive activity of students, in which the quality of students' cognitive activity is implied.

Psychological and pedagogical sciences have established that the important motive of human activity is interest, which emphasizes on the process of selective orientation of a person on certain objects, which manifests itself in the quest to know them, to be engaged in this activity. Some motivated interests are the stimulus of the person's individual activity.

The problem of interest in learning is not new. Its value was confirmed by many scientists (Benson, 2001). In the most diverse interpretations of the problem in classical Psychology (Onufriieva \& Ivashkevych, 2021), the main function of in(c) Ivashkevych Eduard, Onufriieva Liana

DOI (article): https://doi.org/10.32626/2227-6246.2021-54.34-56 
terest was to attract the schoolchild to study, to capture, to encourage, to "catch" so that the schooling for the pupil became desirable, a need without the satisfaction of which it was impossible to reach successful form.

In Cognitive Psychology (Mykhalchuk \& Ivashkevych, 2018), according to a peculiar developmental cell, a number of significant moments of learning are found.

1. Some of them express the unity of the objective and subjective aspects of cognitive activity.

Any educational subject and even an educational task have its objective interesting characteristics, which contain new facts, unknown phenomena. They are in deep relationships and laws that make them different to consider the surrounding world. At the same time, since each subject has its own peculiarities, the whole content of teaching is presented to the student in a diverse and exciting way.

However, all objectively interesting phenomena of the surrounding world, which are contained in generalized knowledge, find their expressions in the paradigm of cognitive interest only when there is a subjective significance for each student. This process of transformation is objectively interesting for the personal significance and it is the main factor in the process of the formation of the student's interest in learning.

2. Another important part of the value of cognitive interest in the process of learning is that it is mostly clearly manifested the regularity of the transition of external to the internal context, which is the essence of the developing education.

Unfortunately, it often happens that the teacher shows the main concern to give an exciting character to the process of studying (the statement makes a beautiful, figurative uses by many technical means of teaching with the help of visualization of information). But after this, the teacher forgets the main thing: all this means, by the choice and manufacture of which he spent a lot of time and efforts, may not touch the internal strings of the teachers' and pupils' cognitive activity.

(c) Ivashkevych Eduard, Onufriieva Liana DOI (article): https://doi.org/10.32626/2227-6246.2021-54.34-56 
DOI: https://doi.org/10.32626/2227-6246.2021-54

2021. випуск 54

Therefore, the tasks are used on multi-level of their understanding by students.

Such kind of cognitive interest is a kind of test, on which the teacher can check and feel the influence of all means having been used in the educational process.

The problem of identifying the psychological and pedagogical patterns of different ways of managing the pupils' English language classroom is the transition of external forms of activity into internal processes. Then the pupils' conditions are extremely important for the effectiveness of learning, they can be solved with the help of cognitive interests.

3. In this case, it is necessary to draw more attention to one more side of the value of cognitive interest in the learning process, which is associated with the psychological structure of the student himself/herself.

The analysis of the psychological structure of cognitive interest lets us to make a conclusion that this is a purely personal entity, coupled with pupils' needs, by which each unity represents all important processes for the individual: intellectual, emotional, volitional ones.

Cognition is impossible without active thoughts, therefore, the processes of thinking are the most significant for increasing a great interest in cognitive sphere of the person, but it has a deal with those people who have absorbed emotional processes, experiences for themselves. At the same time, telling about a cognitive interest, the thought seeks out of the complication, it has no contemplative character; the idea is active, with the aim of solving cognitive problems, combined with volitional processes. Concerning the cognitive interest we'll find out the expression "the thought is freedom, the thought is participation, the thought is experience», which gives a great benefit to the educational process.

4. Under the influence of cognitive interests, all cognitive activities in general and all mental processes that underlie the creative search, research activity, the more active forms that (c) Ivashkevych Eduard, Onufriieva Liana

DOI (article): https://doi.org/10.32626/2227-6246.2021-54.34-56 
DOI: https://doi.org/10.32626/2227-6246.2021-54

2021. випуск 54

the perception proceeds, becomes more acute observation, activates emotional and logical memory, intensifies the person's imagination. And also the activity of pupils becomes more productive. Its energetic resources contribute to longer and more intensive leakage and provide the successful cognitive activity, in turn, strengthen more greater interest in knowledge.

Thus, the inner side of the educational process, represented by cognitive interest, becomes an inexhaustible source that contributes to a more productive flow of cognitive activity.

The purpose of article is: to provide the experimental research of social intelligence of a teacher as a factor of the stimulation of cognitive interests of pupils.

\section{Methods of the research}

The following theoretical methods of the research were used to solve the tasks formulated in the article: a categorical method, structural and functional methods, the methods of the analysis, systematization, modeling, generalization. Also in our research we used empirical methods, such as statement study and molding experiment. With the aim to diagnose the level of the development of social intelligence of teachers we used the test of J. Gilford and M. O'Sullivan «Research of Social Intelligence», adapted by O.S. Mykhailova (Гилфорд \& О’Салливен, 2021).

\section{Results and their discussion}

At the first stage of our research, analyzing the results of teachers of primary school according to intellectual and personal reflection, we emphasize the cognitive content of the professional thinking of these educators. Reflection, to our mind, is an active, thorough and continuous analysis of people's ideas and beliefs from the point of view on what other consequences can lead to. Therefore, reflection inevitably manifests itself in the process of communication, as in a case of primary school teachers it is a condition and a mechanism of intercourse and

(c) Ivashkevych Eduard, Onufriieva Liana DOI (article): https://doi.org/10.32626/2227-6246.2021-54.34-56 
DOI: https://doi.org/10.32626/2227-6246.2021-54

2021. випуск 54

effective communication. Reflection determines such personal qualities of a partner as penetration, sensitivity, patience, invaluable acceptance and understanding of another person.

Reflection gives the teacher the idea of how he/she is perceived as a partner in the process of communication, allowing them to adjust their behavior based on this presentation. Reflection ensures mutual understanding and coherence of the actions of partners in the conditions of cooperating, joint activity. We tell about the mechanism of «removal position», that is a mechanism for entering the positions «above» and «out» of this situation.

Also pretty high results teachers of primary school had for empathy, which, in our opinion, also greatly increased the results of the overall assessment of social intelligence. Empathy is a sensation that transmits such a spiritual unity of the person when one person is so imbued with feelings of another one who temporarily identified himself/herself with an interlocutor, as even to mean dissolving in this process. In this deep process there is a mutual understanding. The empathy of teachers of primary school, in our opinion, correlates with extraversion, in addition, the empathy of primary school teachers positively correlates with the female ability of the psyche to get deep knowledge in any period of his/her life.

Thus, empathy as the ability to resonate emotionally on the experiences of another person has a fairly high level of the development of teachers of primary school, which has expanded their high results of social intelligence. The results of personal qualities, professional skills of primary school teachers facilitate the development of social intelligence of these teachers, were treated by the procedure of factor analyses. As a result, three basic factors were obtained.

To the first, the most significant factor $(72.34 \%$ of dispersion), which we called «The factor of communicative competence, empathy and reflection", with the highest factor weight there were included such characteristics: «the ability to empa(c) Ivashkevych Eduard, Onufriieva Liana

DOI (article): https://doi.org/10.32626/2227-6246.2021-54.34-56 
thize» $(0.83)$, «the ability to initiate a favorable moral climate for pedagogical communication» $(0.82)$, «expressive interactive skills» $(0.78)$, "adequate understanding of the inner world of the interlocutor, empathy in communication» $(0.78)$, «communicative abilities» $(0.76)$, «ability to self-examination and self-knowledge» $(0.73)$, «expressive skills» $(0.73)$, «qualities based on the principles of professional ethics and etiquette" $(0.70)$, "personal reflection» $(0.69)$, "flexibility in the process of communication» (0.68), "the ability to reflex, to reflect in the humanistic educational paradigm, to adequately perceive and understand the identity of the child" (0.68), "the ability and skills to manage their emotional state of the other person, the possession of providing communication techniques" (0.68), "the ability to influence the emotional state of schoolchildren, to improve their mood through humor, encouraging speeches and replicas» (0.64), "the ability to behave carefully and friendly to colleagues and students, to consult with them" (0.63), «predicative empathy» $(0.63)$, «the ability to show argumentation in the communication» $(0.63)$, "cognitive-expressive skills» (0.61), "cognitive empathy» (0.61), «sociability» $(0.60)$, «skill and skills of vertical and non-vertical interaction» (0.59), «cognitive skills» $(0.54)$, «intellectual reflection» $(0.51)$, «skills of constructive behavior in conflict situations» (0.50).

The second factor (21.05\% of dispersion) was named by us as «Prognostic abilities», which included the following characteristics: "the ability to predict a specific result of the activity» (0.63), «the ability to plan and to design» $(0.60)$, «the ability to lead the school team» $(0.54)$, «the ability to predict the development of inter-entity relationships, while using both verbal and non-verbal means, as well as mechanisms of communicative influences - infection, persuasion, suggestion, etc.» (0.53), "the ability to plan cognitive activity of students" (0.53), «the ability to predict their own professional development and development of other people» $(0.50)$.

(C) Ivashkevych Eduard, Onufriieva Liana DOI (article): https://doi.org/10.32626/2227-6246.2021-54.34-56 
DOI: https://doi.org/10.32626/2227-6246.2021-54

2021. випуск 54

And, finally, the third factor (6.61\% of dispersion) was called "Axiological one». It includes only three characteristics: "the value relation of the teacher to himself/herself and the personality of the student» $(0.51)$, «the system of personality attitudes, the experience of interpersonal and professional communication and interactions» $(0.49)$, «the ability to organize business communication» (0.40).

Consequently, the factor analysis having been done by us and the results we have made it possible to conclude that teachers of primary school have a «high» or "above the average» level of the development of social intelligence that is largely ensured by the level of the development of communicative competence, empathy (for example, its cognitive and predicative forms), and also intellectual and personal reflection.

The second stage of the experiment was aimed for studying the level of the development of social intelligence of teachers of teenagers and senior pupils who teach the natural sciences and humanities (S2, N2, M2, P2 groups). We will describe the features in the indicators of social intelligence of teachers of the natural sciences and humanities, which were identified at the stage of empirical research.

Thus, according to Subtest № 3 «Verbal Expressions», which determines the ability to understand the significance of such verbal reactions of people depending on the context of the situation, the rates of women in all groups were slightly higher than the ones of men. Thus, $34.25 \%$ of men and $40.96 \%$ of women were diagnosed with the high level of «verbal expressions» in $\mathrm{S} 2$ group; in N2 group with high results for this subtest were $30.95 \%$ men and $41.16 \%$ women, in M2 group there were $33.12 \%$ of men and $42.68 \%$ of women, and in P2 group there were $33.44 \%$ of men and $45.04 \%$ of women. The difference between these results is rather significant at the level of reliability $\rho<0.05$. Also, quite a large number of respondents in these groups have the average level of the development of social intelligence, based on the responses to «Verbal Expres(c) Ivashkevych Eduard, Onufriieva Liana

DOI (article): https://doi.org/10.32626/2227-6246.2021-54.34-56 
DOI: https://doi.org/10.32626/2227-6246.2021-54

2021. випуск 54

sions» subtest: $38.64 \%$ of men in $\mathrm{S} 2$ group and $33.88 \%$ of women; $39.65 \%$ of men in group N2 and $34.90 \%$ of women; $41.59 \%$ of men in M2 group and $37.28 \%$ of women; $45.70 \%$ of men in group P2 and $35.95 \%$ of women. The difference in the results of the middle level of the development of social intelligence is insignificant among the teachers of the natural sciences and humanities, except for P2 group, where there is a great difference in the mean of verbal expression rates between men and women at the level of reliability $\rho<0.01$. A sufficiently large number of respondents in all groups (up to $30 \%$ ) have a low level of outcomes for this subtest, which, first of all, will reduce the overall composite assessment of social intelligence of teachers of teenagers and senior pupils who teach the natural sciences and humanities, and, secondly, we prove the evidence about the lower level of social intelligence of these teachers compared with primary school teachers, who, as a rule, have a higher than average and the highest level of the development of social intelligence (Table 1).

«S» group includes 103 teachers of the III-d and the II-d categories (professional experience is from 5 to 10 years, the age is up to 30 years). This group includes: 56 teachers of secondary schools № 5, № 15 in Rivne, 23 teachers of Shpanivska and Alexandria secondary schools of Rivne region, 24 teachers of secondary school № 15 in Kamianets-Podilskyi. In turn, all teachers of this group were divided into subgroups, depending on the discipline they teach:

- S1 group includes 34 primary school teachers (of which 4 teachers are men and 30 ones are women);

- S2 group includes 35 teachers of teenagers who teach the natural sciences and humanities (of which 17 teachers are men and 18 ones are women);

- S3 group includes 34 teachers of senior pupils of the physical and mathematical cycle (of which 17 teachers are men and 17 ones are women).

(C) Ivashkevych Eduard, Onufriieva Liana DOI (article): https://doi.org/10.32626/2227-6246.2021-54.34-56 
The levels of the development of social intelligence of teachers of groups S1, S2, S3 (in \%)

\begin{tabular}{|c|c|c|c|c|c|c|}
\hline \multirow{3}{*}{\begin{tabular}{|c|} 
The level of social intelligence \\
of teachers by subtests \\
of the test of J. Gilford and \\
M. O'Sullivan "Research \\
of Social Intelligence», \\
adapted by O.S. Myhailova
\end{tabular}} & \multicolumn{6}{|c|}{ Groups } \\
\hline & \multicolumn{2}{|c|}{ S1 } & \multicolumn{2}{|c|}{ S2 } & \multicolumn{2}{|c|}{ S3 } \\
\hline & men & $\begin{array}{l}\text { wo- } \\
\text { men }\end{array}$ & men & $\begin{array}{l}\text { wo- } \\
\text { men }\end{array}$ & men & $\begin{array}{l}\text { wo- } \\
\text { men }\end{array}$ \\
\hline \multicolumn{7}{|c|}{ I. Subtest «Stories with completion» } \\
\hline High level & 63.2 & 76.2 & 65.1 & 63.2 & 68.3 & 35.1 \\
\hline Middle level & 36.8 & 23.8 & 22.1 & 18.8 & 31.7 & 51.7 \\
\hline Low level & 0 & 0 & 12.7 & 18.1 & 0 & 13.2 \\
\hline \multicolumn{7}{|c|}{ II. Subtest «Groups of expressions» } \\
\hline High level & 66.0 & 64.3 & 30.1 & 41.9 & 65.0 & 36.0 \\
\hline Middle level & 24.5 & 31.2 & 41.8 & 32.8 & 24.8 & 43.7 \\
\hline Low level & 9.46 & 4.53 & 28.2 & 25.3 & 10.6 & 20.3 \\
\hline \multicolumn{7}{|c|}{ III. Subtest «Verbal expression» } \\
\hline High level & 65.1 & 68.0 & 34.3 & 41.0 & 72.4 & 38.4 \\
\hline Middle level & 30.6 & 26.1 & 38.6 & 33.9 & 15.2 & 43.6 \\
\hline Low level & 4.32 & 5.86 & 27.1 & 25.2 & 12.4 & 18.0 \\
\hline \multicolumn{7}{|c|}{ IV. Subtest «Stories with additions» } \\
\hline High level & 69.0 & 77.1 & 42.6 & 31.0 & 75.1 & 38.0 \\
\hline Middle level & 31.0 & 22.9 & 44.2 & 49.1 & 24.9 & 38.9 \\
\hline Low level & 0 & 0 & 13.2 & 20.0 & 0 & 23.1 \\
\hline
\end{tabular}

In general, the data obtained was indicated that women (teachers of the natural sciences) were more sensitive to the nature and various manifestations of human relationships and they were able to show considerable role of flexibility in the situations that were arisen. This may be explained by the fact that education in the paradigm of «love» (passion) for the naC Ivashkevych Eduard, Onufriieva Liana

DOI (article): https://doi.org/10.32626/2227-6246.2021-54.34-56 
tural sciences contributes to the development of women's style aimed at emotional sensitivity, communicative compatibility. Men, on the contrary, are encouraged to develop the ability to hide and suppress their feelings, that is, emotional restraint, competition, activity, the ability to control the situation are encouraged.

So, concerning the social intelligence and its role in teaching activities, the latter should be analyzed in terms of the impact on its productivity, efficiency and conditions of optimization. It should be noted that in the pedagogical activity the concept of "productivity" is considered from the point of view of two positions: functional and psychological productivity. The functional productivity of the teacher's activity is as a clearly constructed system of didactic methods and techniques, the basic updating of which are communicative skills. In such a way psychological productivity is the newness of the personality of a student, the level of his/her social adaptation that will contribute to the process of the development of social intelligence.

\section{Conclusions}

Taking into account the specifics of each particular object, pedagogical activity is built upon the laws of communication. In any classifications the structure of communication in the foreground appears its cognitive aspect, which largely determines the productivity of teaching activities. Thus, we revealed the regularities of the influence of the level of productivity on the understanding of the behavior of the partner in communication, which indicates the actualization of social intelligence. We found that teachers with a low level of pedagogical activity can only perceive external manifestations of the communication of partners, also their behavior without analyzing its goals and motives. However, teachers with a high level of productivity of pedagogical activities can understand the deep essence of the personality-integrational properties of

(c) Ivashkevych Eduard, Onufriieva Liana DOI (article): https://doi.org/10.32626/2227-6246.2021-54.34-56 
DOI: https://doi.org/10.32626/2227-6246.2021-54

2021. випуск 54

the person, identifying the goals and motives of his/her behavior.

Consequently, the productivity of teaching activity directly depends on the effectiveness of the knowledge of a teacher on the personality of students, that is, depends on socio-perceptual peculiarities of both - a teacher and pupils.

To our mind, social intelligence of a teacher is updated due to the mechanisms of knowledge of a teacher the pupils' personal qualities and characteristics. One of such mechanisms is pedagogical social-perceptual stereotyping. For the first time this mechanism was investigated in the experiments, in which positive and negative stereotyping of the pupils' personal qualities and characteristics were determined. Also, we identified the influence of evaluative standard stereotypes on social-perceptual stereotyping. It was proved that the negative influence on interpersonal interaction in the pedagogical process had stereotypes that were taking into account an absolute, unchanging character, but for each teacher there were subjective evaluative stereotypes and the teacher focused on their content for the purpose of the actual subjective assessment of the pupil's personality. Then subsequently, this mechanism of pedagogical activity will facilitate the study of personal qualities and characteristics from a professional point of view. In turn, all this indicates a significant level of the development of social intelligence of a teacher.

\section{Literature}

Гилфорд Дж., О’Салливен М. Тест «Социальный интеллект». В адаптации Е.С. Михайловой. 2021. URL : lib.chdu.edu.ua/pdf/posibnuku/ $160 / 41$.pdf.

Гончарук Н., Онуфрієва Л. Психологічний аналіз рівнів побудови комунікативних дій. Психолінгвістика. Психолингвистика. Psycholinguistics, 2018, 24 (1), 97-117. URL : https://doi.org/10.31470/ 2309-1797-2018-24-1-97-117.

Benson, P. Teaching and Researching Autonomy in Language Learning. Harlow : Longman, 2001. 565 p.

(C) Ivashkevych Eduard, Onufriieva Liana

DOI (article): https://doi.org/10.32626/2227-6246.2021-54.34-56 
Mykhalchuk, N., \& Ivashkevych, E. Psycholinguistic features of the development of social intelligence of the teacher. Психолінгвістика. Психолингвистика. Psycholinguistics, 2018, 23 (1), 242-257. URL : https://zenodo.org/record/1211618.

Mykhalchuk, N., \& Kryshevych, O. The peculiarities of the perception and understanding of Sonnets written by W. Shakespeare by the students of the Faculty of Foreign Languages. Psycholinguistics. Психолінгвістика. Психолингвистика, 2019, 26 (1), 265-285. URL : https://doi.org/10.31470/2309-1797-2019-26-1-265-285.

Nunan, D. (2003). Nine steps to learner autonomy. Retrieved June 20. URL : http://www.andrasprak.su.se/polopoly_fs/1.84007.1333707257!/ menu/standard/file/2003_11_Nunan_eng.pdf.

Onufriieva, L., \& Ivashkevych, Ed. Contemporary approaches to the problem of the development of cognitive activity of pupils according to the ways of managing the young learner's classroom. Збірник наукових праць «Проблеми сучасної психології», 2021, 52, 61-83. URL : https://doi.org/10.32626/2227-6246.2021-52.61-83.

Onufriieva, L. \& Ivashkevych, Ed. The development of learner's autonomy by the way of the formation of social intelligence. Збірник наукових пращь «Проблеми сучасної психологї̈, 2021, 51, 9-32. URL : https://doi.org/10.32626/2227-6246.2021-51.9-32.

\section{References}

Guilford, J., \& O’Sulliven, M. (2007). Test «Sotsialnyi intellekt» [Test «Research of Social Intelligence»]. Retrieved from lib.chdu.edu.ua/ pdf/posibnuku/160/41.pdf [in Russian].

Honcharuck, N., \& Onufriieva, L. (2018). Psykholohichnyi analiz rivniv pobudovy komunikatyvnykh dii [Psychological analysis of levels of communicative actions' constructing]. Psykholinhvistyka. Psikholingvistika. Psycholinguistics - Psycholinguistics. Psycholinguistics. Psycholinguistics, 24 (1), 97-117. Retrieved from https://doi.org/ 10.31470/2309-1797-2018-24-1-97-117 [in Ukrainian].

Benson, P. (2001). Teaching and Researching Autonomy in Language Learning. Harlow : Longman.

Mykhalchuk, N., \& Ivashkevych, E. (2018). Psycholinguistic features of the development of social intelligence of the teacher. Psykholinhvistyka. Psikholingvistika. Psycholinguistics - Psycholinguistics. Psycholinguistics. Psycholinguistics, 23 (1), 242-257. Retrieved from https://doi.org/10.5281/zenodo.1211618.

Mykhalchuk, N., \& Kryshevych, O. (2019). The peculiarities of the perception and understanding of Sonnets written by W. Shakespeare by the

(C) Ivashkevych Eduard, Onufriieva Liana

DOI (article): https://doi.org/10.32626/2227-6246.2021-54.34-56 
DOI: https://doi.org/10.32626/2227-6246.2021-54

2021. випуск 54

students of the Faculty of Foreign Languages. Psykholinhvistyka. Psikholingvistika. Psycholinguistics - Psycholinguistics. Psycholinguistics. Psycholinguistics, 26 (1), 265-285. Retrieved from https:// doi.org/10.31470/2309-1797-2019-26-1-265-285.

Nunan, D. (2003). Nine steps to learner autonomy. Retrieved on June, 20. Retrieved from http://www.andrasprak.su.se/polopoly_fs/1.84007. 1333707257!/menu/standard/file/2003_11_Nunan_eng.pdf.

Onufriieva, L., \& Ivashkevych, Ed. (2021). Contemporary approaches to the problem of the development of cognitive activity of pupils according to the ways of managing the young learner's classroom. Zbirnyk naukovykh prats "Problemy suchasnoi psykholohii» - Collection of research papers "Problems of modern Psychology", 52, 61-83. Retrieved from https://doi.org/10.32626/2227-6246.2021-52.61-83.

Onufriieva, L., \& Ivashkevych, Ed. (2021). The development of learner's autonomy by the way of the formation of social intelligence. Zbirnyk naukovykh prats "Problemy suchasnoi psykholohii»-Collection of research papers "Problems of modern Psychology», 51, 9-32. Retrieved from https://doi.org/10.32626/2227-6246.2021-51.9-32.

Івашкевич Едуард, Онуфрієва Ліана. Соціальний інтелект учителя як чинник стимулювання пізнавальних інтересів учнів

\section{АНОТАЦІЯ}

Mета статmі - провести експериментальне дослідження соціального інтелекту вчителя як чинника стимулювання пізнавальних інтересів учнів.

Для розв'язання поставлених у роботі завдань використано такі теоретичні методи дослідження: категоріальний, структурно-функціональний, аналіз, систематизація, моделювання, узагальнення, а також емпіричні методи, зокрема, констатувальне дослідження й формувальний експеримент. Для діагностики рівня розвитку соціального інтелекту нами застосовано "Методику дослідження соціального інтелекту» Дж. Гілфорда та М. О’Саллівена в адаптації О.С. Михайлової.

Результати дослідження. Отримані дані свідчать про те, що жінки (вчителі природничо-гуманітарного циклу) мають більшу чутливість до характеру та різних проявів людських взаємостосунків і здатні виявляти неабияку рольову гнучкість щодо ситуації, яка виникає. Це пояснюється тим, що виховання в парадигмі «любові» (захоплення) до природничо-гуманітарних дисциплін сприяє розвитку в жінок стилю, спрямованого на C Ivashkevych Eduard, Onufriieva Liana

DOI (article): https://doi.org/10.32626/2227-6246.2021-54.34-56 http://journals.uran.ua/index.php/2227-6246 
емоційну чутливість, комунікативну сумісність. У чоловіків, навпаки, заохочується розвиток здатності приховувати й пригнічувати свої почуття, тобто, заохочується емочійна стриманість, змагальність, активність, здатність до контролю ситуації.

Визначено, що якщо говорити, зокрема, про соціальний інтелект і його роль у педагогічній діяльності, то останню слід аналізувати в аспекті впливу на їі продуктивність, ефективність і умови оптимізації. При цьому слід зазначити, що у педагогічній діяльності поняття «продуктивність» розглядається з двох позицій: як функиіональна і психологічна продуктивність. Функціональними продуктами діяльності педагога $\epsilon$ чітко вибудована система дидактичних методів і прийомів, базовими актуалізаторами яких є комунікативні вміння, а психологічними - новоутворення особистості учня, рівень сочіальної адаптації, які сприятимуть становленню соціального інтелекту.

Висновки. 3 урахуванням специріки кожного конкретного об'єкта педагогічна діяльність вибудовується за законами здійснення комунікації. у будь-якій класифікації структури спілкування на першому плані постає його когнітивний аспект, який значною мірою зумовлює продуктивність педагогічної діяльності. В емпіричному дослідженні виявлено закономірності впливу рівня продуктивності діяльності на розуміння поведінки партнера по спілкуванню, що свідчить про актуалізацію сочіального інтелекту. Нами встановлено, що педагоги з низьким рівнем продуктивності педагогічної діяльності здатні сприймати лише зовнішні прояви поведінки партнера по комунікації, не аналізуючи його цілі та мотиви. Разом із тим, педагоги з високим рівнем продуктивності педагогічної діяльності здатні розуміти глибинну сутність особистісно-інтеграційних властивостей індивіда, виявляючи цілі й мотиви його поведінки.

Доведено, що продуктивність педагогічної діяльності безпосередньо залежить від ефрективності пізнання педагогом особистості учнів, тобто соціально-перцептивних особливостей як учителя, так і школярів.

На нашу думку, соціальний інтелект педагога актуалізується завдяки механізмам пізнання педагогом особистості учня. Одним із таких механізмів є педагогічна соціально-перцептивна стереотипізація. Нами встановлено вплив оцінних еталонів-стереотипів на соціально-перцептивну стереотипізацію. Доведено, що негативний вплив на міжособистісну взаємодію в педагогічному процесі мають стереотипи, які

(C) Ivashkevych Eduard, Onufriieva Liana DOI (article): https://doi.org/10.32626/2227-6246.2021-54.34-56 
DOI: https://doi.org/10.32626/2227-6246.2021-54

2021. випуск 54

набувають абсолютного, незмінного характеру, але якщо для педагога домінуючими є суб'єктивні оцінні стереотипи, і вчитель орієнтується на їх зміст із метою власне суб'єктивної оцінки особистості учня, то згодом цей механізм педагогічної діяльності фасилітуватиме вивчення особистості з професійної точки зору. Своєю чергою, все це свідчить про неабиякий рівень розвитку соціального інтелекту педагога.

Ключові слова: соціальний інтелект, стимулювання пізнавальних інтересів учнів, міжособистісна взаємодія, комунікація, емоційна чутливість, комунікативна сумісність.

\section{Ивашкевич Эдуард, Онуфриева Лиана. Социальный интеллект учителя как фактор стимулирования познавательных интересов учащихся}

\section{АННОТАЦИЯ}

Цель статьи - провести экспериментальное исследование социального интеллекта учителя как фактора стимулирования познавательных интересов учащихся.

Для решения поставленных в работе задач использованы следующие теоретические методы исследования: категориальный, структурно-функциональный, анализ, систематизация, моделирование, обобщение, а также эмпирические методы, в частности, констатирующий и формирующий эксперимент. Для диагностики уровня развития социального интеллекта мы использовали "Методику исследования социального интеллекта» Дж. Гилфорда и М. О'Салливена, адаптированную E.C. Михайловой.

Результаты исследования. Полученные данные свидетельствуют о том, что женщины (учителя естественно-гуманитарного цикла) имеют большую чувствительность к характеру и различным проявлениям человеческих взаимоотношений и способны проявлять большую ролевую гибкость относительно возникающей ситуации. Это объясняется тем, что воспитание в парадигме "любви» к естественно-гуманитарным дисциплинам способствует развитию у женщин стиля, направленного на эмоциональную чувствительность, коммуникативную совместимость. У мужчин, наоборот, поощряется развитие способности скрывать и подавлять свои чувства, то есть, поощряется эмоциональная сдержанность, состязательность, активность, способность к контролю ситуации.

(C) Ivashkevych Eduard, Onufriieva Liana

DOI (article): https://doi.org/10.32626/2227-6246.2021-54.34-56 
Определено, что если говорить, в частности, о социальном интеллекте и роли последнего в педагогической деятельности, то последнюю следует анализировать в аспекте влияния на ее производительность, эффрективность и условия оптимизации. При этом следует отметить, что в педагогической деятельности понятие "производительность» рассматривается с двух позиций: как функциональная и психологическая производительность. Благодаря функциональным продуктам деятельности педагога четко выстроена система дидактических методов и приемов, базовыми актуализаторами которых выступают коммуникативные умения, а психологическими - новообразования личности ученика, уровень его социальной адаптации, способствующие становлению социального интеллекта.

Выводы. Доказано, что с учетом специфики каждого конкретного объекта, педагогическая деятельность выстраивается по законам осуществления коммуникации. В любой классификации структуры общения на первом плане находится его когнитивный аспект, который во многом предопределяет производительность педагогической деятельности. В эмпирическом исследовании выявлены закономерности влияния уровня производительности деятельности на понимание поведения партнера по общению, что свидетельствует об актуализации социального интеллекта. Установлено, что педагоги с низким уровнем производительности педагогической деятельности способны воспринимать только внешние проявления поведения партнера по коммуникации, не анализируя его цели и мотивы. Вместе с тем, педагоги с высоким уровнем производительности педагогической деятельности способны понимать глубинную сущность личностно-интеграционных свойств индивида, проявляя цели и мотивы его поведения.

Доказано, что производительность педагогической деятельности напрямую зависит от эффрективности познания педагогом личности учащихся, то есть социально-перцептивных особенностей как учителя, так и школьников.

По нашему мнению, социальный интеллект педагога актуализируется благодаря механизмам познания педагогом личности учащегося. Одним из таких механизмов является педагогическая социально-перцептивная стереотипизация. Нами установлено влияние оценочных эталонов-стереотипов на социально-перцептивную стереотипизацию. Доказано, что негативное влияние на межлиностное взаимодействие

(C) Ivashkevych Eduard, Onufriieva Liana DOI (article): https://doi.org/10.32626/2227-6246.2021-54.34-56 
DOI: https://doi.org/10.32626/2227-6246.2021-54 2021. випуск 54

в педагогическом процессе оказывают стереотипы, которые принимают абсолютный, неизменный характер. В случае если для педагога доминирующими являются субъективные оценочные стереотипы, и учитель ориентируется на их содержание с целью собственно субъективной оценки личности ученика, то впоследствии этот механизм педагогической деятельности будет фасилитировать изучение личности с профессиональной точки зрения. В свою очередь, все это свидетельствует о высоком уровне развития социального интеллекта педагога.

Ключевые слова: социальный интеллект, стимулирование познавательных интересов учащихся, межличностное взаимодействие, коммуникация, эмоциональная чувствительность, коммуникативная совмесmuмость.

Original manuscript received September 22, 2021 Revised manuscript accepted October 31, 2021

C Ivashkevych Eduard, Onufriieva Liana

DOI (article): https://doi.org/10.32626/2227-6246.2021-54.34-56 http://journals.uran.ua/index.php/2227-6246 